\title{
An electrophoretically detectable modification of glucosephosphate isomerase in mouse spermatozoa
}

\author{
Mia Buehr and Anne McLaren \\ M.R.C. Mammalian Development Unit, Wolfson House (University College London), \\ 4 Stephenson Way, London NWI 2HE, U.K.
}

\begin{abstract}
Summary. Cellulose acetate electrophoresis of glucosephosphate isomerase (GPI) from mouse testis and spermatozoa revealed a minor band which is not seen in electropherograms of GPI from other tissues. The minor band is associated equally with the two electrophoretic variants of GPI examined. Treatment of tissue extracts with various enzymes, enzyme inhibitors or thiol reagents failed to alter the appearance or position of the minor bands in sperm and testis GPI, or to induce their appearance in GPI from other tissues. No minor bands were seen in electropherograms of testis GPI from immature males, or from males whose testes lack spermatozoa for genetic reasons.
\end{abstract}

\section{Introduction}

Enzymes are known to occur in different forms (isoenzymes) due, for example, to allelic differences at a single structural locus, to coding by multiple structural gene loci, or to post-translational modification (such as the addition of sialic acid residues). The allelic forms characterize different individuals and segregate in normal Mendelian fashion, while the isoenzymes determined by multiple gene loci, or the modified forms, may be expressed in different organs or different developmental stages of the same individual (for a review, see Edwards \& Hopkinson, 1977). Evidence is accumulating that the testis is distinctive in its enzymic constitution, showing some enzymes (e.g. lactate dehydrogenase-X) not seen in other organs (Goldberg, 1977). A testis-specific isoenzyme might characterize either the somatic tissue of the testis, or the spermatogenic cells. In this paper we describe a modification of glucosephosphate isomerase in the mouse which appears to be confined to spermatozoa.

Glucosephosphate isomerase (EC 5.3.1.9) occurs most frequently in the mouse as one of two electrophoretic variants, designated GPI-1A and GPI-1B (De Lorenzo \& Ruddle, 1969) although a third isoenzyme has been described (Padua, Bulfield \& Peters, 1978). The isoenzymes GPI-1A and GPI-1B are coded for by alleles Gpi-1 ${ }^{\mathrm{a}}$ and Gpi-1 ${ }^{\mathrm{b}}$ respectively. The enzyme is a dimer, and animals heterozygous at the Gpi-1 locus exhibit a hybrid band (formed by the association of A and B subunits) as well as the two parental bands.

\section{Materials and Methods}

Stocks used. Mice from several strains were examined. Some were homozygous for Gipi-1 ${ }^{\bar{a}}$ (MF1, BALB/c, and a multiple recessive stock) or for Gpi-1 ${ }^{\mathrm{b}}$ (C57BL/McL), and in others both alleles were segregating (the random-bred $\mathrm{Q}$ strain, and a stock derived from a cross between the multiple recessive stock and $\mathrm{C} 57 \mathrm{BL} / \mathrm{McL}$ ). 
Sample preparation. Sperm samples virtually free of somatic cell contamination were obtained by pressing lightly along the length of the isolated vas deferens under a dissecting microscope, so as to express the dense core of spermatozoa with minimal escape of blood. They were washed and frozen in an equal volume of phosphate-buffered saline (PBS; Dulbecco ' $A$ ': Oxoid), pH 6.9. One testis of each individual was fixed in Bouin's fluid, sectioned at $8 \mu \mathrm{m}$ and stained with haematoxylin and eosin, while the other was stripped of its tunica albuginea and incubated in a collagenase solution (70 units $/ \mathrm{ml}$ ) in Whittingham's medium (Whittingham, 1971) at $37^{\circ} \mathrm{C}$ for $4-5 \mathrm{~h}$. It was then possible to free the spermatogenic tubules from interstitial tissue by gentle pipetting and rinsing in PBS. Red blood cell lysates were prepared according to the method of West (1977). All other tissues were minced finely and frozen in an equal volume of PBS. All tissues examined (except blood cells) were frozen-thawed twice and centrifuged for 10 min at approximately $1500 \mathrm{~g}$ before application of the supernatant to the electrophoresis gel. No attempt was made to quantify GPI activity in the various tissue samples examined, but it was found that equal volumes of samples prepared as described above yielded electrophoretic bands of roughly equal intensities.

Incubations. The effects of pronase (at $2.5,0.5$ and $0.25 \mathrm{mg} / \mathrm{ml}$ final concentrations) hyaluronidase (150, 100 and 50 units $/ \mathrm{ml}$ ), trypsin and chymotrypsin (both at 5,1 and 0.5 $\mathrm{mg} / \mathrm{ml})$, ram acrosin $(1 \mathrm{mg} / \mathrm{ml})$, neuraminidase $(0.5$ units $/ \mathrm{ml})$, trypsin inhibitor from soybean $(0.5$ and $0.2 \mathrm{mg} / \mathrm{ml})$, para-aminobenzamidine $(1 \mathrm{mg} / \mathrm{ml})$, maleic acid $(5 \mathrm{mg} / \mathrm{ml})$ and oxidized glutathione $(12 \mathrm{mg} / \mathrm{ml})$ were examined. To achieve these final concentrations, tissue supernatants were mixed with the appropriate amounts of the above reagents in PBS (with the exception of neuraminidase, which was made up in $0.05 \mathrm{M}$-phosphate-citrate buffer at $\mathrm{pH} .0$ ) and incubated at $37^{\circ} \mathrm{C}$ for $1 \mathrm{~h}(3 \mathrm{~h}$ for neuraminidase, and up to $24 \mathrm{~h}$ for mixtures of testis and somatic tissue supernatants). All reagents were obtained from Sigma except the acrosin, which was a gift from Dr R. A. P. Harrison. This was preparation FD (Brown, Andani \& Hartree, 1975) with a specific activity of approximately 30 units of BAEE-splitting activity $/ \mathrm{mg}$.

Electrophoresis. Electrophoresis was done on cellulose acetate gel strips, $2.5 \times 17 \mathrm{~cm}$ in size. For a general description of the 'Cellogel' system and its use, see Meera Khan (1971). The bridge width was $11 \mathrm{~cm}$ and samples were applied, with a 'Cellogel' semi-micro applicator, to the strips midway between the bridge shoulders. The bridge buffer was $0.1 \mathrm{M}$-Tris-glyci ie, $\mathrm{pH} 8.5$, and gels were normally run at $200 \mathrm{~V}$ for $2 \mathrm{~h}$ at room temperature. In this system GPI moves towards the cathode, with the A form moving more slowly than the B. The stain used consisted of $8 \mathrm{mg}$ fructose 6-phosphate, $8 \mathrm{mg} \mathrm{MgCl}_{2}, 4 \mathrm{mg}$ NADP, $4 \mathrm{mg}$ nitro blue tetrazolium, $2 \mathrm{mg}$ phenazine methosulphate, and 10 units glucose 6-phosphate dehydrogenase (all from Sigma) in $2 \mathrm{ml} 0.05 \mathrm{M}$-Tris- $\mathrm{HCl}$ buffer, $\mathrm{pH} 8.0$, and mixed immediately before use with $4 \mathrm{ml}$ rolten $2.5 \%$ agar made up in the same buffer. The main GPI bands appeared within 2-3 min or aining, and the minor bands (see below) within $15 \mathrm{~min}$.

\section{Results}

GPI from testis and spermatozoa of all normal adult males examined exhibited a subsidiary minor band appearing anodal to each main band (Pl. 1, Fig. 1). The staining intensity of this minor band was judged by eye to be approximately $10 \%$ of that of the main band. The distance between the minor and the main band was slightly greater than that between the normal A and B bands; it did not vary between strains or between GPI genotypes. Heterozygous individuals, with a 3-banded GPI phenotype, exhibited a 3-banded pattern of minor bands as well. When staining of the gels was done in the absence of substrate (fructose 6-phosphate) no bands were seen. When other tissues (blood, kidney, lung, stomach, intestine, liver, spleen, muscle, heart and brain) were examined for these minor GPI bands, all but muscle and liver clearly lacked any comparable band. In GPI electropherograms from muscle and liver tissues a generei. area of 
PLATE 1

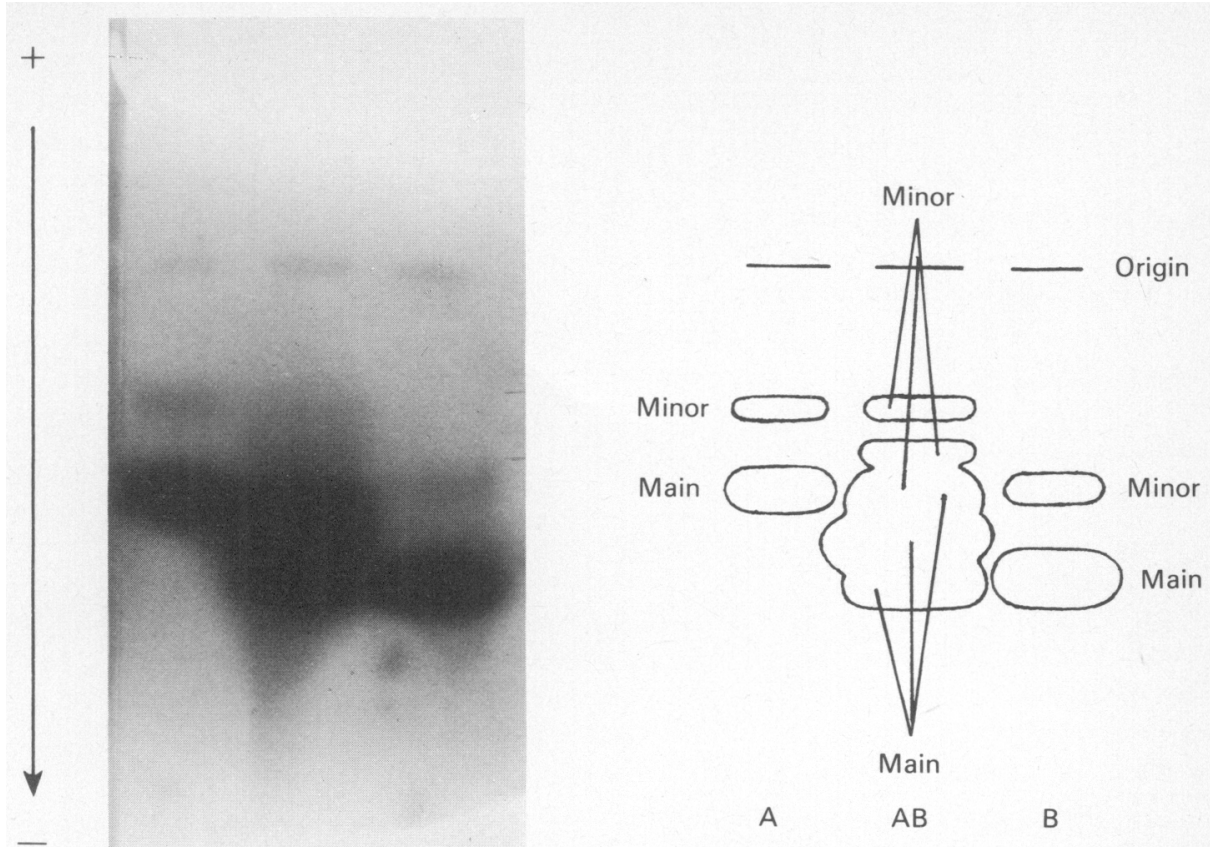

Fig. 1

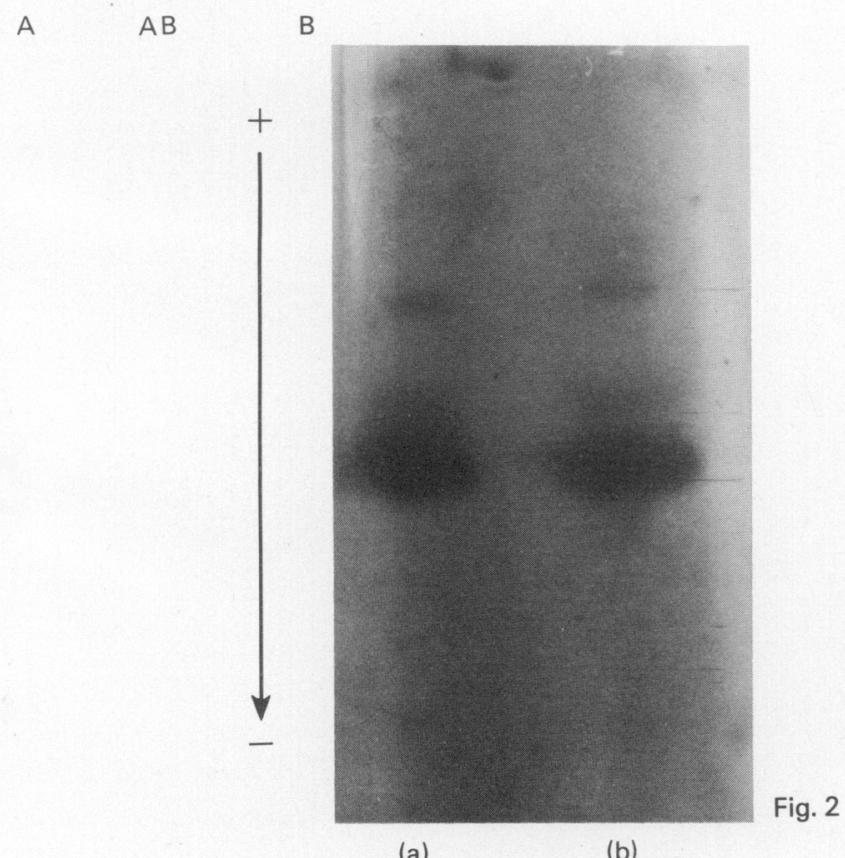

(a)

(b)

Fig. 1. Electropherogram and diagram of testis GPI showing main and minor bands of the A, $\mathrm{AB}$ and $\mathrm{B}$ phenotypes. The gels were allowed to overstain in order to increase the intensity of the minor bands.

Fig. ?. Electropherogram of GPI from (a) liver and (b) testis. Although there is an area of diffuse activity trailing behind the main band of liver GPI, there is no clearly defined minor band. 
activity could be seen extending from the main band to the minor band position, but there was no indication of a clearly defined minor band (Pl. 1, Fig. 2). GPI from most tissues exhibited the weak trailing bands described by De Lorenzo \& Ruddle (1969), but these did not correspond in position to the sperm and testis-specific minor band. In an attempt to modify the position or appearance of the minor bands or to induce their appearance in tissues other than testis or spermatozoa, tissue samples were incubated with various enzymes, enzyme inhibitors or thiol reagents. Incubation of testis, sperm, blood and liver supernatants with pronase, hyaluronidase, trypsin, chymotrypsin, acrosin, neuraminidase, soybean trypsin inhibitor, para-aminobenzamidine, maleic acid or oxidized glutathione resulted in neither the selective abolition of minor bands or alteration of minor band position in the germinal samples, nor the induction of minor bands in the somatic samples, although incubation with some of the higher concentrations of proteolytic enzymes resulted in a reduction of staining intensity in all GPI bands. Incubation of blood or liver samples from Gpi-1 ${ }^{a}$ animals together with testis or spermatozoa samples from Gpi-1 $1^{\text {b }}$ animals for periods up to $24 \mathrm{~h}$ failed to induce the appearance of GPI-1A minor bands. Length and condition of sample storage, or temperature at which electrophoresis was carried out, appeared to have no effect on minor bands: samples collected and run on ice immediately after collection were indistinguishable in minor band pattern from those stored at 0 to $5^{\circ} \mathrm{C}$ or at room temperature for up to 5 days and run at room temperature (although long storage at room temperature did increase the strength of other small trailing bands in all tissues). Incubation of samples at $50^{\circ} \mathrm{C}$ for $1 \mathrm{~h}$ reduced the intensity of staining of GPI from all tissues, but had no specific effect on the minor bands.

The minor bands appear to be characteristic of spermatozoa and mature testis only, as testes from newborn animals showed no minor band activity. Twenty males were killed between 30 and 43 days of age; one testis was analysed for GPI pattern and the other examined histologically for the presence of condensing spermatids or spermatozoa in the seminiferous tubules (Table 1). The appearance of the minor bands seems to be a function of the age of the mouse, or of the associated progression of spermiogenesis.

Table 1. Presence of minor bands in GPI from testes of young males correlated with age and with presence of condensing spermatids in the seminiferous tubules

\begin{tabular}{|c|c|c|c|}
\hline $\begin{array}{l}\text { Minor bands } \\
\text { in testis GPI }\end{array}$ & $\begin{array}{l}\text { No. of } \\
\text { males }\end{array}$ & Mean $\underset{\text { (days) }}{ \pm}$ s.e.m. age & $\begin{array}{l}\text { Mean } \pm \text { s.e.m. } \% \\
\text { tubules containing } \\
\text { condensing } \\
\text { spermatids }\end{array}$ \\
\hline Absent & 6 & $31.3 \pm 0.5$ & $41 \cdot 1 \pm 9.5$ \\
\hline Faint & 7 & $36.4 \pm 1.3$ & $65.6 \pm 9.5$ \\
\hline Strong & 7 & $37.4 \pm 1.0$ & $75 \cdot 4 \pm 6 \cdot 3$ \\
\hline
\end{tabular}

A further indication of an association between minor band appearance and spermiogenesis is provided by our findings in sub-fertile and sterile males. Two males, XO in chromosome constitution and heterozygous for the dominant gene Sex-reversed (Sxr), were examined. In XO (unlike XX) $S x r /+$ males, the germ cells can undergo spermatogenesis, and spermatozoa may be formed, but these are abnormal and incapable of fertilization (Cattanach, Pollard \& Hawkes, 1971). In one of our males, spermatogenesis appeared to be blocked at the spermatid stage, and no minor bands could be seen on the gel. In the other, about $40 \%$ of the tubules contained mature spermatozoa, and a faint minor band was found. Testes from one male heterozygous for the T145H translocation did not exhibit minor bands. Lyon \& Meredith (1966) report that spermatogenesis in such males is arrested in meiosis and that few if any maturing spermatids are seen in the testis. 


\section{Discussion}

The appearance of tissue-specific minor bands in electropherograms of spermatozoa and testis GPI is probably dependant on the nature of the electrophoresis system used. A. C. Peterson (personal communication) reports that minor bands do not appear when sperm GPI is run on a Tris-citrate, $\mathrm{pH} 7 \cdot 2$, starch gel system. The possibility must be considered that these minor bands are artefacts representing normal GPI that has been altered as a consequence of sample preparation, storage and electrophoresis. Hopkinson (1970) describes a variant of human GPI (PHI) that exhibits modified band patterns after storage, and Harrison (1972) has reported a conversion of hexokinase in sperm extracts that appears to be due to endogenous proteinase action. However, neither storage nor enzyme treatment had any such effect on the bands we describe, and the correlation of minor band appearance with the presence of maturing spermatozoa suggests that the minor bands are not artefacts, but represent modifications made to the enzyme in vivo. Since the band is also seen in extracts of pure spermatozoa recovered from the vas deferens, its appearance in extracts of spermatogenic tubules is likely to be due to the spermatozoa or sperm precursor cells that these contain, rather than to any somatic component of the testis. The absence of the band in GPI from immature testes, in which the majority of the tubules lack spermatozoa, and in adult testes that for genetic reasons contain no spermatozoa, suggests that it is characteristic of spermatozoa only.

The fact that the minor band is associated equally with the $A$ and $B$ forms of the enzyme indicates that it is a post-translational modification rather than the expression of a different structural gene. It is possible that similar modifications of other sperm enzymes, such as the NAD(P)H diaphorase DIA 3 (Edwards, Potter \& Hopkinson, 1979), enolase (Edwards, Lacki \& Hopkinson, 1981) and hexokinase (Goldberg, 1977) may occur. A number of other enzymes are known to occur in forms specific to spermatozoa and testis, including acrosin (Polakoski \& McRorie, 1973), sperm hyaluronidase (Zaneveld, Polakoski \& Schumacher, 1973), LDH-X (Markert, 1971), hexokinase (Harrison, 1972), phosphoglycerate kinase (VandeBerg, Cooper \& Close, 1973) and other (Goldberg, 1977).

We are grateful to Dr R. A. P. Harrison, Dr D. A. Hopkinson, Dr A. C. Peterson and Dr Y. H. Edwards for their helpful comments on the manuscript, as well as to Dr Harrison for his gift of acrosin.

\section{References}

Brown, C.R., Andani, Z. \& Hartree, E.F. (1975) Studies on ram acrosin. Isolation from spermatozoa, activation by cations and organic solvents, and influence of cations on its reaction with inhibitors. Biochem. J. 149, 133-146.

Cattanach, B.M., Pollard, C.E. \& Hawkes, S.G. (1971) Sex-reversed mice: $\mathrm{XX}$ and $\mathrm{XO}$ males. Cytogenetics 10, 318-337.

De Lorenzo, R.J. \& Ruddle, F.H. (1969) Genetic control of two electrophoretic variants of glucosephosphate isomerase in the mouse (Mus musculus). Biochem. Genet. 3, 151-162.

Edwards, Y.H. \& Hopkinson, D.A. (1977) Developmental changes in the electrophoretic patterns of human enzymes and other proteins. In Isozymes: Current Topics in Biological and Medical Research, vol. 1, pp. 19-78. Eds M. C. Ratazzi, J. G. Scandalios \& G. S. Whitt. Alan R. Liss, New York.
Edwards, Y.H., Potter, J.E. \& Hopkinson, D.A. (1979) A comparison of the biochemical properties of the human diaphorase (DIA $)$ isozymes determined by the common alleles $D I A_{3}^{1}, D I A_{3}^{2}$ and $D I A_{3}^{3}$. Ann. Hum. Genet. 42, 293-302.

Edwards, Y.H., Lacki, C. \& Hopkinson, D.A. (1981) Enolase in human sperm. Biochem. Soc. Trans. 9, 257P, Abstr.

Goldberg, E. (1977) Isozymes in testes and spermatozoa. In Isozymes: Current Topics in Biological and Medical Research, Vol. 1, pp. 79-124. Eds M. C. Ratazzi, J. G. Scandalios \& G. S. Whitt. Alan R. Liss, New York.

Harrison, R.A.P. (1972) Interconversion of hexokinase enzymes in mammalian spermatozoa. $J$. Reprod. Fert. 31, 510-511.

Hopkinson, D.A. (1970) The investigation of reactive sulphydryls in enzymes and their variants by 
starch-gel electrophoresis: studies on the human phosphohexose isomerase variant PHI 5-1. Ann. Hum. Genet. 34, 79-84.

Lyon, M.F. \& Meredith, R. (1966) Autosomal translocations causing male sterility and viable aneuploidy in the mouse. Cytogenetics 5, 335-354.

Markert, C.L. (1971) Isozymes and cellular differentiation. Adv. Biosciences 6, 511-528.

Meera Khan, P. (1971) Enzyme electrophoresis on cellulose acetate gel: zymogram patterns in manmouse and man-Chinese hamster somatic cell hybrids. Arch. Biochem. Biophys. 145, 470-483.

Padua, R.A., Bulfeld, G. \& Peters, J. (1978) Biochemical genetics of a new glucosephosphate isomerase allele $\left(\mathrm{Gpi}^{\mathrm{i}} \mathrm{1}^{\mathrm{C}}\right)$ from wild mice. Biochem. Genet. 16, 127-143.
Polakoski, K.L. McRorie, R.A. (1973) Boar acrosin. II. Classification, inhibition and specificity studies of a proteinase from sperm acrosomes. J. biol. Chem. 248, 8183-8188.

VandeBerg, J.L., Cooper, D.W. \& Close, PJ. (1973) Mammalian testis phosphoglycerate kinase. Nature, New Biol. 243, 48-49.

West J.D. (1977) Red blood cell selection in chimaeric mice. Expl Hemat. 5, 1-7.

Whittingham, D.G. (1971) Culture of mouse ova. $J$. Reprod. Fert., Suppl. 14, 7-21.

Zaneveld, L.J., Polakoski, K.L. \& Schumacher, G.F.B. (1973) Properties of acrosomal hyaluronidase from bull spermatozoa. Evidence for its similarity to testicular hyaluronidase. J. biol. Chem. 248, 564 570.

Received 26 November 1980 